\title{
"BRS URS ENTREVERO" - NEW WHITE CLOVER FORAGE CULTIVAR FOR SOUTH BRAZIL
}

(D) Daniel Portella Montardo' ${ }^{1}$, (1) Miguel Dall' Agnol $^{2}$, (D) Roberto Luis Weiler ${ }^{2}$, D Maurício Marini Köpp ${ }^{1}$, (1) André Pich Brunes ${ }^{2}$ and (1) Carine Simioni*

1 Embrapa Pecuária Sul, BR 153, Km 633 - Vila Industrial, C.P. 242, 96401-970, Bagé, RS, Brazil; 2 Universidade Federal do Rio Grande do Sul, Faculdade de Agronomia, Av. Bento Gonçalves 7712, CEP 90001-970, Porto Alegre, RS, Brazil.

*Corresponding author: Carine Simioni (carine.simioni@ufrgs.br)

\begin{abstract}
BRSURS Entrevero" is a white clover cultivar, indicated for intercropping with winter grasses and for oversowing natural and subtropical pastures in areas with high fertility and humidity. It has high quality and forms a mat of stolons that covers completely the soil, with a prostrate habit with the growth buds close to the surface, resulting in a high grazing aptitude.
\end{abstract}

Keywords: Legume, plant breeding, Trifolium repens.

\section{Introduction}

The Trifolium genus means three-leaved and refers to the genus's leaves, which are typically palmate with three leaflets. Trifolium repens, commonly called white clover or Dutch Clover, which survive by spreading stolons that form new roots at nodes) rooted nodes. The axillary buds on these rooted stolons can give rise to new plants (Nelson et al., 2020).

Although native to Europe, this plant has naturalized throughout temperate zones in lawns, fields, and roadsides. White clover is an excellent nitrogen fixing plant and can be used as forage plant and for livestock in crop rotation.

Forage legumes are the key to maintaining soil fertility, and providing high protein forage for ruminant livestock. Grass-legume mixes such as ryegrass-clover swards are commonly used in agricultural grassland because the system has the ability to be nitrogen self-sufficient, being economically and ecologically sustainable (Lüscher et al., 2014).

The presence of white clover in swards can increase the total forage yield, corresponding to the addition of more than $240 \mathrm{~kg}$ of $\mathrm{N}$ applied (Enriquez-Hidalgo et al., 2015).

The diversification of species in pastures allows a momentary and temporal increase in production as well as an improvement in the quality of the ingested forage mass. The productivity benefit of a diversified ecosystem has been attributed to either species complementarity where resources are used more efficiently by a greater number of species (Loreau and Hector, 2001).

Thus, the forage plants breeder's main focuses are the improvement of species that enable the farmers to have a range of species for use in their properties with high gains in most the seasons. 


\section{Pedigree and breeding method}

"BRS URS Entrevero" is a white clover cultivar improved in southern Brazil and the only one with registration and protection at the Brazilian Ministry of Agriculture, Livestock and Food Supply (MAPA).

The genetic material used in the breeding program was formed by 49 genotypes collected in Eldorado do Sul/RS and Santa Vitória do Palmar/RS, after a severe drought period in 1997. In 1998, the plants were cloned through vegetative propagation (stolons) in a greenhouse, producing between 6 and 10 clones per genotype, at the Agronomy School of UFRGS/Porto Alegre, RS. In the same year, a polycross block was installed, with six replications (clones) and later the seeds were harvested separatelyper plant, at the Experimental Agronomic Station of UFRGS/Eldorado do Sul, RS.

In addition, in 1999, at the experimental station, a progeny test was performed, and the six most productive genotypes were selected to form the new population. In 2000 the mother plants of the six selected genotypes were crossed and the seeds mixed in equal amounts to form the selected population. From 2001 to 2005, seed multiplication of the selected population was carried out with the elimination of atypical plants and from 2006-2009, Value for Cultivation and Use (VCU) and Distinctness, Uniformity and Stability (DUS) tests start to be performed.

\section{Performance}

The white clover "BRS URS Entrevero" has an average length of internodes of $2.51 \mathrm{~cm}$ and 13.8 inflorescences per plant. The leaves are large, with medium green color, with high density and high intensity of white marks on the leaves.

The Internodes are thick with medium to long size and the plants are semi-erect with high regrowth capacity. The sites where the evaluations were conducted are shown in Table 1 . The fresh green forage yield and dry matter yield in three locations and for three years compared to two commercial cultivars are shown in Tables 2 and 3.

Table 1. Characterization of the evaluation sites of the cultivar "BRS URS Entrevero".

\begin{tabular}{|c|c|c|c|c|}
\hline City/State & Altitude & Latitude & Sowing & Soil Type \\
\hline Coronel Barros/RS & 311 & 2822'59" & May de 2006 & \multirow{3}{*}{ Haplortox } \\
\hline Coronel Barros/RS & 311 & $28 \div 22^{\prime} 59^{\prime \prime}$ & May de 2007 & \\
\hline Coronel Barros/RS & 311 & $28 \div 22^{\prime} 59^{\prime \prime}$ & June de 2008 & \\
\hline Bagé/RS & 230 & 31으'52" & May de 2006 & \multirow{3}{*}{ Alfisol } \\
\hline Bagé/RS & 230 & $31920^{\prime} 52^{\prime \prime}$ & May de 2007 & \\
\hline Bagé/RS & 230 & $3120^{\prime} 52^{\prime \prime}$ & June de 2008 & \\
\hline Eldorado do Sul/RS & 40 & $30 \div 06^{\prime} 22^{\prime \prime}$ & May de 2006 & \multirow{3}{*}{ Ultisol } \\
\hline Eldorado do Sul/RS & 40 & $30 \div 06 ' 22^{\prime \prime}$ & May de 2007 & \\
\hline Eldorado do Sul/RS & 40 & $30 \div 06^{\prime} 22^{\prime \prime}$ & June de 2008 & \\
\hline
\end{tabular}

Table 2. Fresh green forage yield $\left(\mathrm{kg} \mathrm{ha}^{-1}\right)$ of cultivar "BRS URS Entrevero" in three locations and for three years compared to two commercial cultivars.

\begin{tabular}{lcccc}
\hline Location & Year & \multicolumn{2}{c}{$\begin{array}{c}\text { Fresh green forage yield } \text { (kg ha }^{-1} \text { ) } \\
\text { “i }\end{array}$} & Zapicán \\
\hline Coronel Barros/RS & 2006 & 22453 & 29860 & 20917 \\
\hline Coronel Barros/RS & 2007 & 25450 & 21100 & 21287 \\
\hline Coronel Barros/RS & 2008 & 26163 & 34964 & 35355 \\
\hline Bagé/RS & 2006 & 37209 & 36224 & 40912 \\
\hline Bagé/RS & 2007 & 9559 & 10926 & 8275 \\
\hline Bagé/RS & 2008 & 11007 & 9320 & 9167 \\
\hline Eldorado do Sul/RS & 2006 & 14796 & 9525 & 11987 \\
\hline Eldorado do Sul/RS & 2007 & 14593 & 15703 & 12212 \\
\hline Eldorado do Sul/RS & 2008 & 18331 & 18739 & 17791 \\
\hline Mean & & $\mathbf{1 9 7 3 0}$ & $\mathbf{2 0 7 0 7}$ & $\mathbf{1 9 7 6 0}$ \\
\hline
\end{tabular}


Table 3. Dry matter yield $\left(\mathrm{kg} \cdot \mathrm{ha}^{-1}\right)$ of cultivar "BRS URS Entrevero" in three locations and for three years compared to two commercial cultivars.

\begin{tabular}{lcccc}
\hline \multirow{2}{*}{ Local } & Year & \multicolumn{3}{c}{ Dry matter yield $\mathbf{~ k g ~ h a ~}^{-\mathbf{1}} \mathbf{)}$} \\
& & “BRS URS Entrevero” & Yi & Zapicán \\
\hline Coronel Barros/RS & 2006 & $* 3817$ & 5136 & 3263 \\
\hline Coronel Barros/RS & 2007 & 3792 & 3587 & 3491 \\
\hline Coronel Barros/RS & 2008 & 4446 & 5874 & 5480 \\
\hline Bagé/RS & 2006 & 6214 & 5651 & 6096 \\
\hline Bagé/RS & 2007 & 1281 & 1639 & 1324 \\
\hline Bagé/RS & 2008 & 1453 & 1398 & 1531 \\
\hline Eldorado do Sul/RS & 2006 & 2323 & 1543 & 1918 \\
\hline Eldorado do Sul/RS & 2007 & 2434 & 2434 & 2125 \\
\hline Eldorado do Sul/RS & 2008 & 3098 & 3092 & $\mathbf{3 1 1 5}$ \\
\hline Mean & & $\mathbf{3 2 0 6}$ & $\mathbf{3 3 7 2}$ & \\
\hline
\end{tabular}

\section{Adaptation}

The white clover "BRS URS Entrevero" is recommended for inclusion in mixes with winter active grasses and for oversowing into natural and subtropical pastures to improve the quality of the diet in areas with good fertility and humidity, but does not tolerate soil with moisture in excess. (Sheaffer et al., 2020).

This cultivar is indicated for the three states of the South Brazil, mainly for the places with milder temperatures during the summer, such as of $C f b$ climate.

This is characterized by, temperate oceanic climate, where the coldest month average is above $0{ }^{\circ} \mathrm{C}\left(32^{\circ} \mathrm{F}\right)\left(\right.$ or $-3{ }^{\circ} \mathrm{C}\left(27^{\circ} \mathrm{F}\right)$, all months present an average temperatures below $22{ }^{\circ} \mathrm{C}$ $\left(71.6^{\circ} \mathrm{F}\right)$, at least four months averaging above $10{ }^{\circ} \mathrm{C}\left(50^{\circ} \mathrm{F}\right)$ and no significant precipitation differ-rence between seasons (Köeppen, 1948).

\section{Seed production}

"BRS URS Entrevero" is registered by the Brazilian Ministry of Agriculture, Livestock and Food Supply (MAPA) with number 31189 $(11 / 10 / 2013)$ and the protection number 2160073 (18/04/2016). Genetic seed stock is maintained by EMBRAPA Pecuária Sul, BR 153, Km 633 Vila Industrial, P. B. 242, 96401-970, Bagé, RS, Brazil. Certified seed are produced by the SouthBrazilian Association for the Promotion of For age Research - SULPASTO and is available for sowing on commercial field in the seasons 2021.

\section{Acknowledgments}

We thank the CAPES (Brazilian Federal Agency for Support and Evaluation of Graduate Education), CNPq (Brazilian Council for Scientific and Technological Development) and the South-Brazilian Association for the Promotion of Forage Research (SULPASTO) for financial support and grants.

\section{References}

ENRIQUEZ-HIDALGO, D.; GILLILAND, T.J.; HENNESSY, D. 2015. Herbage and nitrogen yields, fixation and transfer by white clover to companion grasses in grazed swards under different rates of nitrogen fertilization. Grass and Forage Science, 71(1):559-574. doi: https://doi.org/10.1111/gfs.12201

KÖEPPEN, W. 1948. Climatologia: com un estudio de los climas de la tierra. Fondo de Cultura Economica, México, 478 p.

LOREAU, M.; HECTOR, A. 2001. Partitioning selection and complementarity in biodiversity experiments. Nature, 412:72-76. DOI: https://doi.org/10.1038/35083573 
LÜSCHER, A.; MUELLER-HARVEY, I; SOUSSANA, J.F.; REES, R.M.; PEYRAUD, J.L. 2014. Potential of legume-based grassland-livestock systems in Europe: a review. Grass Forage Science, 69(2):206-228. https://doi.org/10.1111/gfs.12124

NELSON, C.J.; MOORE, K.J.; COLLINS, M.; REDFEARN, D.D. 2020. Perspectives, Terminology and Classification. In: Moore, K.J.; Collins, M.; Nelson, C.J.; Redfearn, D.D. (eds) Forages: The Science of Grassland Agriculture. John Wiley \& Sons, Croydon, p. 3-21.

SHEAFFER, C.C.; EVERS, G.W.; JUNGERS, J.M. 2020. Cool-Season Legumes for humid Areas. In: Moore, K.J.; Collins, M.; Nelson, C.J.; Redfearn, D.D. (eds) Forages: The Science of Grassland Agriculture. John Wiley \& Sons, Croydon, p. 263 - 275. 